\title{
Chief Mohlomi: A Mosotho Model of Ethics and Morality in Public Administration and Governance
}

\author{
Khali Mofuoa \\ Charles Sturt University \\ E-mail: khalimo25@gmail.com
}

Received: Nov. 18, 2020 Accepted: Jan. 23, $2021 \quad$ Online published: Feb. 2, 2021

doi:10.5296/jpag.v11i1.17950～URL: https://doi.org/10.5296/jpag.v11i1.17950

\begin{abstract}
Ethics or morals are learned as they are observed from people's life histories - present or past. They are best remembered in relationships with life histories of impeccable models of ethics or morals in their respective societies. The Sesotho-speaking people of Lesotho and South African province of Free State, known as Basotho, often refer to the high ethical standards or principles of Chief Mohlomi in the administration and governance of public affairs, and talk of him as one of history's great ethical or moral leaders of all time in southern Africa. But do such claims about Chief Mohlomi have substance, and do they withstand scrutiny in public administration and governance? If so, how? Drawing lessons primarily from the pre-colonial 18th-century history of the Basotho, the article explores such claims, and also sheds some light on the relevance of the legendary Chief Mohlomi in public administration and governance not often discussed in academia.
\end{abstract}

Keywords: Mohlomi, Moshoeshoe, Basotho, Lesotho, southern Africa, Setho and Botho, Ethics or Morals, Public Administration and Governance

\section{Introduction}

That ethics or morals are an inherent, invaluable, and essential factor in the administration and governance of public affairs in societies is no illusion. According to Johnson (2019), "this statement could not be truer today, and surely ethically" instructive for students of public administration and governance given "the well-known fact that public administrators are held at a much higher standard concerning ethics," (Johnson, 2019) - what Mofuoa (2012:194) dubs 'ethic of responsibility' if a moral society is to be borne. In the era of intensified technology-assisted public probity nowadays, "much of the ethical rhetoric has fallen [or is falling] by the wayside" (Johnson, ibid). The resultant outcome is that "many public officials are being plastered with [negative] controversy in the media [with] the public [increasingly] demand[ing] answers and justice from all public servants who are involved with such 
controversy" (Johnson, ibid). Here, Chedondo (2019) provides the sober assessment of state of administration and governance of public affairs in our contemporary time thus,

There is no doubt that there is a leadership problem of crisis proportion in general. Media is usually replete with stories about unethical leadership that in most cases manifest itself in the form of corruption in government [which] implies eroded integrity, and a general lack of concern for the wellbeing of others.

In general, ethics or morals are defined as the ideals, values, or standards that people use to determine whether their actions are morally good or bad or ethically acceptable or unacceptable. Consequently, ethics or morals in public administration and governance are understood as encompassing moral value judgments covering administration and governance of public affairs. In this regard, borrowing from Wilsonian tradition and wisdom, public administration is understood as encompassing all administrative activities of ethically managing and directing public affairs. In contrast, governance is understood as the exercise of administrative authority or power ethically in managing and directing public affairs.

In his first political announcement on March 9, 1832, Abraham Lincoln - the 16th President of the United States - wrote, "I desire to see a time when morality [or ethics in public administration and governance] shall become much more general than at present" (Lincoln, 1832). Similarly, Horace Mann - the nineteenth-century champion of the common schools strongly advocated for moral education. He and his followers were worried by the widespread drunkenness, crime, and poverty during the Jacksonian period in which they lived. Of concern, too, were the waves of immigrants flooding into cities, unprepared for urban life, and particularly unprepared to participate in the democratic civic life. Mann and his supporters saw free public schools as the ethical leaven of society. In his final report to the Massachusetts Board of Education, Mann wrote that if children could experience "the elevating [ethical or moral] influences of good schools, the dark host of public crimes could be banished from the world" (Mann, 1849:96).

Indeed, Sloan (1980), quoted in Amy (1983), noted that throughout most of the nineteenth century, the most basic course in the college curriculum was moral philosophy, usually taught by the college president and required of all senior students. The moral philosophy course was regarded as the capstone of the curriculum. It aimed to pull together, integrate, and give meaning and purpose to the student's entire college experience and study course. In so doing, it even more importantly sought to equip the graduating seniors with the ethical sensitivity and insight needed to put their newly acquired knowledge to use in ways that would benefit not only themselves and their achievement but also the larger society. As Phenix (1961), a Proponent of Education for Reverence once said

The most crucial education product is a constructive, consistent, and compelling system of values around which personal and social life may be organized. Unless teaching and learning provide such a focus, all the particular knowledge and skills acquired are worse than useless. An 'educated' person whose information and ability are directed to no personally appropriate worthy ends is a menace to himself and society. A highly sophisticated society educated to no coherent way of life is likewise by its very learning made them more prone to disease and degeneration.

Like Lincoln (1932), Mann (1849), Phenix (1961), and Sloan (1980), Chief Mohlomi (1720 -1815), a Mosotho moral philosopher, seemed to have understood the importance and need for moral education in the Basotho society of his time in present-day Lesotho. Mohlomi 
aimed his moral teachings at the society or community he was living in and the problems of his time. The societal issues that Mohlomi's people struggled with at the end of the 18th century were the abuse of power by chiefs, armed conflict between clans and tribes, alcohol and dagga abuse, witchcraft, and the weak position of women and children. Most of the Mohlomi's proverbial sayings that have become a part of Basotho morality, and indeed survived until now in present-day Lesotho had to do with these issues, which were enemies of ethics or morality in the public administration and governance of society of his time.

This article presents Chief Mohlomi, hereafter called Mohlomi, as a model of ethics and morality in public administration and governance from whom today's public administrators can learn valuable lessons. The article contends that Mohlomi could provide legendary insights (or wisdom) into the adjustments required to ethical thinking for public administration and governance in contemporary times. It should be noted that the article is not necessarily putting Mohlomi forward as the highest authority of ethics or morals for public administration and governance. It merely tries to open up new vistas, to transcend prevailing assumptions and paradigms by entering, and taking seriously, ways of thinking quite different from our own. Readers should think of the article as an experiment in which a test is being done to establish if the past can illuminate some issues in the administration and governance of public affairs. The article implores readers to hypothetically remove the notion that renowned thinkers from the past are fundamentally circumscribed by the exigencies of their time instead of attending to their every word as something that possibly speaks to us.

\section{Mohlomi and moral problems of public administration and governance in his time}

Mohlomi was a Mosotho chief who lived around 1720 - 1815 in the Caledon Valley, which now forms the border between present-day South Africa and Lesotho. He was born around 1720 at Fothane near the present-day town of Fouriesburg in the Free State province, South Africa north of Lesotho (Machobane, 1978; Ellenberger, 1912 cited in Mofuoa, 2015: 103). He was born during the great migration of the Basotho in search of a suitable settlement. Struggles for status and power, which resulted in movements of emerging political groupings, characterized the migration period. These political devolutions among Basotho tribes were often marked by violence and death. His father, Monyane, and brother Nkopane became victims of these violent wars (Ellenberger, 1912: 64). This history of violent and fragmented political dispersal among Basotho tribes was well known to Mohlomi, who was convinced that it was "a needless and self-defeating way of life" (Machobane, 1978: 9 cited in Mofuoa, 2015: 103). This conviction shaped his administration and governance of public affairs in confronting the moral problems of his time.

Before the 1800s, the Basotho were loose communities set within small chiefdoms with no overall ruler (Mothibe, 2002 cited in Mofuoa, 2016: 165). Although patriarchy and communal ownership elements were widely practiced, most of the customs and traditions were generally in flux (Gill, 1993 cited in Mofuoa, 2016: 165). One author has described Basotho traditions at the time as "frequently innovative, localized and contested" (Epprecht, 1992 cited in Mofuoa, 2016: 165). This nature of the Basotho traditions explains the socio-political problems of Mohlomi's time that shaped his administration and governance of public affairs 
during unprecedented times in the history of Basotho. During his time, these socio-political problems included but were not limited to abuse of power by chiefs, armed conflict between clans and tribes, abuse of alcohol and dagga, witchcraft, and weak position women and children as vulnerable people of which he vehemently preached against them.

Legendary Basotho historians have it that while his contemporaries made their names in the annals of history on the battlefield, Mohlomi first made his mark in his society in the administration and governance of public affairs. As a Ngaka (doctor) and Moroka-pula (rainmaker), Mohlomi had a very high reputation in Lesotho and throughout southern Africa (Machobane, 1978: 9). He travelled (i) on calls for healing and rain-making services (Machobane, 1978: 12-13 cited in Mofuoa, 2015: 104) and (ii) in search of knowledge and remedies (MacGregor, 1905: 13 cited in Mofuoa, 2015: 104). Indeed, according to Mofuoa, "As a keen political observer, his medicine and rain-making travel[s] enabled him to preach peace and resolve conflicts through peaceful means in societies he visited in Lesotho and throughout southern Africa" (Mofuoa, 2015:104).

Mohlomi was a celebrated chief and sage as well (Machobane, 1978: 16). As a chief, Mohlomi conduct of the political affairs of the people of Monaheng-one of Basotho tribes-was admirable and exemplary (Machobane, 1978: 16 cited in Mofuoa, 15: 104), and "his government was that of a prince distinguished for clemency and wisdom" (Arbousset \& Daumas, 1846:272-275 cited in Mofuoa, 2015: 104). As a sage, Mohlomi was considered "the wisest man that had ever lived" (Machobane, 1978: 17). His proverbial aphorisms like medicine for a village is a good heart, and it is better to grow corn than to brandish the spear, which spelled the themes of peace and justice showed his sagacious frame of mind on socio-political matters. Mohlomi is also credited for playing a special philosophical role in the field of ideas outside the scope of Basotho's collective wisdom. He was indeed a renowned philosopher of his time, always preoccupying his mind with existence questions (Machobane, 1978:18; Arbousset in Ellenberger, 1912: 92). He was an acclaimed prophet whose prophecies made him a leading figure of his time. Indeed, from his birth, he is said to have been mystic - "reportedly, the ancestors (Balimo) told him in a dream to rule with wisdom and justice and to care for the needy" (Prozesky, 2016:9).

Mohlomi lived at Ngoliloe (meaning 'where one has written') near the present towns of Ficksburg and Clocolan in the Free State province of South Africa. This was the place where Mohlomi chieftaincy headquarters were. It was also the place where Mohlomi established his leadership academy and taught lessons of the art of governing people. One of the students of the Mohlomi's academy at Ngoliloe was a young Lepoqo, whose initiation name was Letlama, the astute Mosotho who later gained fame under the name of Moshoeshoe (Ellenberger, 1912: 107). One of the enduring legacies of Mohlomi is perhaps the political instructions he gave to Moshoeshoe who later became a king, founder and father of modern-day Basotho Society. Mohlomi instilled in Moshoeshoe, respect for the sanctity of the human being and a human being connectedness to other people. It was at Ngoliloe where Mohlomi ultimately met his death at 96 years around 1815 . From one of his many travels, “... on the way home he fell ill with inflammation of the bowels, and had to be carried home to Ngoliloe...He did not live many days longer" (Ellenberger, 1912: 96). Such was the end of Mohlomi - a celebrated 
doctor, an insatiable and upbeat traveller, a rainmaker, a political consultant, a philosopher, a chief, and a prophet (Machobane, 1978:5 Mofuoa, 2015: 104) - but his legendary, remarkable and unrelenting efforts in shaping the society of his time are still fondly remembered in Lesotho and throughout southern Africa.

\section{Mohlomi moral teachings and exemplary behavior in public administration and governance}

Mohlomi's moral teachings and works remain particularly instructive for the administration and governance of public affairs, given his successful application of unorthodox philosophies in illuminating his moral teachings and exemplary behavior. He has made a penetrating contribution to Basotho morality in the administration and governance of public affairs, which remains instructive points of departure today. As such, whatever was the focus of his teachings and works, they are bound to provoke widespread moral interest and attention to modern-day Lesotho, where he is remembered as a man who laid down the philosophy of life for Basotho Society. According to Mokhehle, he is a designer of the Basotho's modern-day society through the philosophical principles he propounded, canvassed, and popularized (Mokhehle, 1976). His renowned student King Moshoeshoe, the founder of the Basotho nation from the ashes of Lifaqane wars in southern Africa in the early nineteenth century, practiced these principles.

Confronted by his time's moral exigencies and controversies, Mohlomi perceived tuition as the ethical leaven of the Basotho society of his time. He saw concern for moral virtues, such as love, peace, honesty, responsibility, compassion, and respect for others, as moral education tenets. In this regard, moral education refers to helping people acquire those virtues or moral habits that will help them individually to live good lives and, at the same time, become productive, contributing members of their communities. In his view, moral education should contribute to the people as individuals and the social cohesion of a community. His prime concern for moral education turned Mohlomi into a traveler of the highest order, preaching his philosophy of life called Setho - a belief system of humane purity of thought and unmitigated truthfulness (Mokhehle, 1976 cited in Mofuoa, 2016:98), which remains central in the moral foundation of Basotho ( Mofuoa, 2018). Its maxims live onto this modern-day Lesotho (Futhwa, 2011 cited in Mofuoa, 2016) and what Mokolatsie (2019) dubs "Sesotho speaking cultures in Southern Africa" or "Sesotho-speaking people of Southern Africa" (Prozesky, 2016). He taught Setho guides leadership to respond in the best possible way to any given situation of administration and governance of public affairs. He maintained that only Setho could motivate a leader to achieve administration and governance excellence of public affairs in every kind of situation. Mohlomi's concept of Setho as the agency behind administration and governance in public affairs is closer in meaning to the notion of love in Christian teaching. In the Christian Bible, Paul, one of Jesus' chief followers, in his account of love, describes it as kind, patient, not envious, and never overbearing (Goggins, 2009).

In Lesotho, Mohlomi is affectionately remembered as the man who used Eastern and Western ideas in his moral teachings but never met anyone from those cultures. There were very few, if any, leaders or philosophers in the world at the time who preached love, tolerance, women's 
rights, peace, democracy, and abstinence (du Preez, 2003:16). As a renowned pacifist himself, he walked all over southern Africa, learning about other people's cultures and languages, healing people, and spreading his message of love. For him, love was the core value of Setho, which lays the foundation for administration and governance of public affairs. Perhaps, his most notable teaching about love was the one he delivered to young Moshoeshoe (c.1786-1870), who asked for medicine to make him a great chief. He replied to Moshoeshoe thus:

There is no herb, no medicine, and no form of talisman that can be used to help anyone to become a chief. The only talisman that I know of is a man's own heart-performances of simple acts of genuine and human love change human hearts toward good and have the power of winning people's hearts (Mokhehle, 1976:31).

Closely associated with Mohlomi's message of love was the message of peace. He is renowned for having not only preached peace but practiced it as a core value of Setho. He disbanded his fighting units in his time, telling the warriors to grow food and look after the women and children rather than make war. 'It is better to thrash the corn than to shape the spear' was one of his famous sayings. According to him, at the heart of administration and governance of public affairs is a civilizing mission: during war and devastation, chaos and internecine destruction, the responsible leader pursues peaceful and productive alliance, succors refugees, and uses the instruments of power to provision and repopulate the land. He is remembered as a man who started the custom of greetings among the Basotho of raising an open palm and proclaiming "khotso" - peace when meeting or seeing strangers. In one of his teaching about peace, he advised Moshoeshoe thus: At all times, I beseech you, learn upon this 'rod of peace.' You must always keep it clear in your mind that it is far more profitable to harvest sorghum than to sharpen spears; a knob-stick by far becomes an instrument of value when it is used to harvest sorghum in the grain fields than when it is engaged in killing men in the battlefields (Mokhehle, 1976:32). In turn, Moshoeshoe called peace his sister, which became his favourite saying and 'guardian angel' for the rest of his life (Mofuoa, 2015).

Tolerance and compassion as core values of Setho were also at the heart of Mohlomi's teachings (Dreyer, 2005; Mokhehle, 1976; Sanders, 1975). Indeed, Mohlomi was renowned for practicing the understanding that no person, however poor, should not be denied justice. In this regard, Sanders says Mohlomi "was also probably the first chief to carry out on an extensive scale of the policy of paying the bohali (i.e., lobola), or marriage cattle, for those of his retainers whose families were too poor to pay it for them" (Sanders, 1975: 21). Teaching about tolerance and compassion, Mohlomi is credited to have advised Moshoeshoe to perform his public administration and governance duties in all their affairs in Setho (Mokhehle, 1976: 31-32). One of his famous saying about tolerance and compassion as agencies behind administration and governance of public affairs was 'Morena ke Morena ka Sechaba,' i.e., a chief is a chief only by his people's grace. The other was 'Conscience is the true guide of a man, it shows him his duty always: if he does well it smiles on him and reproaches him if he does ill' truly portrays what a great thinker and how ethically grounded, morally balanced he was as a leader of his time.

Indeed, according to Mofuoa, it is not overstretching things "to conclude that his 
sophisticated moral teachings; his remarkable moral philosophy, which compares with the most famous philosophers of his time in West and East, was completely original, untouched by external influences (Mofuoa, 2015: 111). In fact, for Mofuoa, "this conclusion is based on the fact that there is no evidence to suggest that Mohlomi met a Caucasian [i.e. white-skinned person of European origin] before his death in 1815, although from his extensive travels throughout southern Africa, he knew of the presence of [European] settlers in the south and on the east coast of modern-day South Africa" (Mofuoa, 2015: 111).

There is no doubt that Mohlomi's philosophical teachings essentially formed the basis or foundation for the present-day Basotho's administration and governance of public affairs. Indeed, the great influence and impact that Mohlomi's philosophical teachings exerted and still exerts on the administration and governance of public affairs in Basotho society is remarkable. The utility of Mohlomi's philosophical teachings was and is still that they covered all aspects of social, economic, spiritual, environmental and political life. These teachings are so comprehensive and all-embracing that if they are well understood and strictly adhered to in Lesotho, southern Africa and indeed the whole of Africa, there will be efficiency, quality service delivery, accountability and transparency in the activities of government and governance. By extension, this will stem the tide of endemic corruption, maladministration, bad leadership and widespread insecurity which have hampered the development of African countries today.

\section{Mohlomi and his ethical system of Botho in public administration and governance}

Mohlomi was renowned for his sense of Botho as the essence of Setho-his philosophy of life. The term Botho describes a person who has a well-rounded character, well-mannered, courteous, and disciplined and realizes his or her full potential both as an individual and as a part of the community to which they belong. Conceptually, Botho "core defining values are humaneness, solidarity, sharing, universal brotherhood, communalism, interdependence, and hospitality" (Mapadimeng, 2009: 76 cited in Mofuoa, 2016: 103). It speaks to the maxim that "a person is a person through other persons," or as Mbiti puts it, "I am because we are and since we are therefore I am" (Mbiti, 1988:108). Botho derives its expression in Sesotho, saying 'motho ke motho ka batho,' which translates into a human being is a human being because of other human beings (Letseka, 2012: 55). It is not overstretching things to say that Botho as a philosophy of social interaction and ethics in modern-day Lesotho was a social construct of Mohlomi to educate Basotho to be morally and ethically upright. Mohlomi is credited for propounding, canvassing, and popularizing Botho in his philosophical teachings in all its manifestations - social, economic, spiritual, environmental, and political. It is not surprising that concepts relating to administration and governance of public affairs in Mohlomi's teachings embody the idea of Botho-respect for the sanctity of the human being and a human being connectedness to other people. Indeed, it is not farfetched to say that the rise of Moshoeshoe in administration and governance of public affairs is connected to the legendary Mohlomi's teachings (Riep, 2011; Mofuoa, 2015). In fact, Prozesky (2016:9) makes a valid point that "Moshoeshoe cannot be well understood without an awareness of the part played in his formation by his remarkable mentor, Chief Mohlomi." 
Mohlomi is perhaps best known for the political instruction he gave to Moshoeshoe, whose agency was Botho. His political philosophy stemmed from a 'miraculous' experience during his initiation. The roof of his initiation hut opened up, and he was brought before his ancestors, who told him to rule with Botho-compassionate humanism (du Preez 2004:15). According to Mohlomi, the essence of Botho as a moderator of political behavior instructs that (i) the practice of virtue and discipline are prerequisite for the successful governance of people, (ii) the great ruler is he who could attract people to him by persuasion and moral example rather than by force or bullying; and (iii) in statecraft, greatness lay not in holding power for its own sake but using power to defend and protect the weak. Machobane (2008:7) eloquently puts Mohlomi's moral teachings of leadership in the administration and governance of public affairs to Moshoeshoe, thus

May your hand be beautiful, i.e., full of generosity and not out for a person's body, i.e., seek to harm your subjects, for as your country's proverb has it, 'The stick has no kraal,' i.e., dictatorship holds no social value.

Mohlomi preached the ethics of democracy in the administration and governance of public affairs, whose agency is Botho. He advised Moshoeshoe to employ the Pitso (public meeting) as a valuable democratic institution in the conduct of his people's daily affairs (Ashton, 1967:30; Mofuoa, 2020: 230). In effect, the Pitso provided the Basotho with a useful forum for ensuring public accountability by leaders. Each individual, regardless of his status, freely expressed his views at such meetings. The origin of the famous maxims goes as follows 'even Motinyane i.e. ordinary person expressed his personal views,' another one is 'Mo-oa-khotla ha a tsekisoe", that is, one who goes astray in the assembly shall not be chastised for it (Ashton, 1967). Put differently, "Mo-oa-khotla h'a tsekisoe - what is said at court is not blameworthy" (Guma, 1967:84 cited in Mofuoa, 2020: 277). The maxims, indeed, have become part and parcel of the lifestyle of the Basotho. This practice shows the freedom of speech regardless of individual status, strengthening the saying that 'morena ke morena $\mathrm{ka}$ batho'- chief is a chief by his people's grace (Ashton, 1967:37). It implied a different philosophy of leadership, constitutionally formulated by cooperative and shared authority - a leader governed through clusters of institutions tasked with participatory management of public affairs (Mahao, 2010:322).

Mohlomi also preached the ethics of political power in the administration and governance of public affairs, whose agency is Botho. He is credited for his historical prohibition of medicine murders for power in Basotho culture during his famous meeting with Moshoeshoe, who asked him for 'power' medicine. Medicine murders were a perversion of old practices of using medicine to 'place' and protect new chiefs and villages (Eldredge, 2007:196). Mohlomi refused 'placing' medicine for power, and consequently, refused 'power' medicine to Moshoeshoe "when he begged him to give him a talisman or medicine that would enable him to become a powerful chief" (du Preez, 2004: 53). His words to Moshoeshoe were that 'Motse ha ona sehlare,' i.e., a village does not have protective medicine (Eldredge, 2007:197) or that 'Motse ha o na sehlare; sehlare ke pelo, i.e., power is not acquired by medicine; the heart is the medicine (du Preez, (2004: 53) are still preserved in modern-day Lesotho. For Mohlomi, contrary to popular belief, there was no medicine for acquiring power or becoming 
a successful ruler. The way to achieve this ambition was and is by having a good heart and treating actual and potential followers with kindness (Mokhehle, 1976:31).

Mohlomi preached ethics of tolerance and compassion in the administration and governance of public affairs, whose agency is Botho. He is said to have advised Moshoeshoe as follows: Always be slow to take to arms... learn to understand men and know their ways. Learn to bear with their human weaknesses and shortcomings. Always determine to direct them along the paths of truth and purity. According to Dreyer (2005: 4), Moshoeshoe stood apart from Shaka, the Zulu King in the present-day province of KwaZulu-Natal in South Africa (concerning tyrannical outbursts) in line with his charge received from Mohlomi, namely "not to kill people, to provide a haven and so on, during the wars of devastation." Mohlomi convinced Moshoeshoe of the political value of diplomacy as opposed to military alliance and subjugation, to have given him the medicine of leadership, and to have instructed him in the acquisition and judicious exchange, lending, and donation of land and cattle as the means of state-formation. Mohlomi is credited to have further advised Moshoeshoe as follows,

Travellers of all types should be fully protected throughout the areas of your chieftainship. Fugitives escaping death and persecution in their homelands should find a ready sanctuary in your land. You should protect them. The land you shall rule should be a home to travellers and fugitives (Mokhehle, 1976:32).

Mohlomi is also known for preaching ethics of war in the administration and governance of public affairs whose agency is Botho. According to Casalis (1861) Moshoeshoe learned all these from his mentor, Mohlomi, who remains a very prominent figure in Basotho history because of his unparalleled wisdom during his time. He had taught Moshoeshoe to: deal justly with all, especially the poor; to love peace more than war and never kill anyone accused of witchcraft. Moshoeshoe was instilled with the conviction that, above all, successful leadership emerged from the practice of virtue and personal discipline in the Morena (or chief). Mohlomi also taught Moshoeshoe that a wise king would seek peaceful relations with his neighbors and only resort to war when presented with no alternative, but then fight with great purpose. He proposed a political policy that is anti-war and conquest to Moshoeshoe. It was the practice of these beliefs that would elevate the rule of Moshoeshoe above mere political considerations in the eyes of his people and inspired complete devotion from them.

Mohlomi is also known for preaching ethics of diplomacy in the administration and governance of public affairs, whose agency is Botho. Mohlomi traveled a lot to make friends with other indigenous nations in southern Africa, which today could be termed establishment of diplomatic ties or international relations. From this, it could be deduced that there was some form of devolution of power because, in the absence of the monarch, there would always be someone to look after the nation's affairs at district and regional levels. Hence the Sesotho dictum: Morena ha a ete, i.e., the chief is never absent (cf. Sekese, 1978; Guma, 1971). He taught his protégé, Moshoeshoe, the value of diplomacy in public administration and governance. As a result of this tutoring, Moshoeshoe paid tribute to the Zulu King, Shaka when he learned that he was preparing to attack him. Together with other gifts, he sent Shaka ostrich feathers. Moshoeshoe also gave cattle to the cannibals who had devoured his grandfather - because they must have been too hungry - instead of viewing them as enemies. Seeking to avoid war from Ngwane of Chief Matiwane, who unseated several Basotho clans and expanded to his kingdom's border, Moshoeshoe paid tribute to Motiwane. Moshoeshoe 
also faced attack at the Ndebele leader Mzilikazi whose forces were defeated by Basotho warriors. In yet another display of diplomatic expertise, Moshoeshoe reportedly sent a cattle offering and a message of salute for the Ndebele warriors and their chief. Thereafter, Chief Mzilikazi and Ndebele people never bothered the Basotho again.

From the above, it is evident that Botho became a national philosophical principle and humane practice, which gave content to live for Basotho during Mohlomi's time and even after. The influence of Botho on social space in pre-colonial, colonial, and post-colonial Lesotho cannot be over-emphasized. It became an ethical system that guided Basotho's philosophy of life as propounded, canvassed, popularized, and kept alive by Mohlomi. Indeed, Mohlomi's ethical system of Botho is useful in that in the midst of high moral failures in government and governance nowadays, Mohlomi as an authoritative and highly respected voice from the past is pointing the way to things that can bring about safer and saner society in our contemporary time.

\section{Mohlomi - a justified model of Basotho morality in public administration and governance}

Scholars in responsible leadership in the administration and governance of public affairs (Doh \& Stumpf, 2005; Maak \& Pless, 2006; Waldman \& Galvin, 2008) advocate the importance of balanced morality - that is, ensuring sustainable business without compromising the natural environment and the livelihood of future generations. Such advocacy has long ago been the essence of Mohlomi teachings and practice. He believed and taught that responsible leaders require a values radar, the ability to scan moral, social, ecological, and cultural developments and assess and weigh the impact of organizational behavior on all relevant stakeholders (Pless \& Maak, 2005). As Gardner notes, "We must hope that our leaders will help us keep alive values that are not so easy to embed in laws. Our feeling about individual responsibility, about caring for others, about honor and integrity, about tolerance and mutual respect, and fulfilment within a framework of values" (Gardner, 1990: 77). Indeed, Moshoeshoe built Basotho nation on the core moral values of administration and governance of public affairs kept alive by Mohlomi.

Mohlomi did not only preach his moral values at the core of the administration and governance of public affairs, but he lived them. As a chief, he judged fairly, never allowing an individual's wealth to influence his decision (Rosenberg \& Veisfelder, 2013: 350). He prohibited the persecution of suspected witches and refrained from 'eating up' his subjects' wealth (Rosenberg \& Veisfelder, ibid). His wealth came from his services as a ngaka, i.e., doctor and moroka-pula, i.e., rainmaker (Rosenberg \& Veisfelder, 2013: 350; van Wyk. 1996:22). He travelled much of Southern Africa from which he acquired cattle from his services. Thus, his ability to acquire wealth as a doctor and rainmaker made him refrain from raiding others' cattle. This may have also been due to his aversion to violence. With the cattle he acquired from his services, he could marry the daughters of many chiefs he visited during his lifetime. He was the first chief in the region to use marriage to create political alliances, which were critical for peace-building amongst societies during his time. He is the first chief in the region to pay bohali, i.e., lobola, for his male followers who did not possess the necessary cattle. It was these attributes that made Mohlomi a successful chief of his time.

Typically, Mohlomi is regarded as the most intelligent and respected man amongst the Basotho (Ellenberger, 1912). In his time, leaders took his counsel on administration and 
governance of public affairs seriously because of his exemplar behavior. Although Mohlomi was a chief in his own right, he was not a very hands-on one (du Preez, 2003). He preferred to leave to the elders most of the decisions about the affairs of his chiefdom. He disbanded his fighting units and told the warriors to grow food and look after women and children rather than make war. His most famous saying in this regard was that 'It is better to thrash the corn than to sharpen the spear' (Gill, 1993:60, sic; cf. Couzens, 2003:50-51). Mohlomi sought to live in peaceful coexistence with his neighbors and encouraged thrift and industry habits among his people. For him, it is far more profitable to harvest sorghum than to sharpen spears. Also, for him, a knob stick by far becomes an instrument of value when used to harvest sorghum in the grain fields than when it is engaged in killing men on the battlefields.

Mohlomi laid down the philosophy of life-truthfulness, justice, peace, love, compassion, equality, tolerance, conciliation, respect, discipline, democracy, neighborliness, and friendship - as adduced from the creative mental and physical experience of the Basotho Society. Moshoeshoe built the Basotho nation on the philosophical principles propounded, canvassed, and popularized by Mohlomi. As Mokhehle (1976: XVi -XViii) notes, "Mohlomi was the designer of the society of the Basotho people. Moshoeshoe, guided by Mohlomi's teachings, became the architect, the builder of the Basotho nation". To impress on Mohlomi's moral legacy for modern-day Basotho society, Mokhehle (1976: ibid) interestingly argues that,

For it is not stretching the point that what Jesus Christ was to Paul, what Karl Marx was to Lenin or Mao-Tse-Tung, so was Mohlomi to Moshoeshoe. Jesus, Marx, and Mohlomi laid down new principles for the recasting of human society. Paul, Lenin, and Moshoeshoe, each in his field, built up new societies, state structures, and religious institutions to make a human society a surety for man's humane existence in this world.

From his studies, Mohlomi developed a political philosophy that he practiced and passed on to Moshoeshoe as his disciple. His philosophy cannot be found in long manuscripts, but it has been captured in Sesotho language maxims or proverbs, which have since been passed down to succeeding generations (Gill, 1993:24, 59). Such adages or proverbs include but not limited to the following: A chief is a chief by the people (van Wyk, 1996:24); a village does not have protective medicine (Eldredge, 2007:197; When thou shalt sit in judgment, let thy decisions be just and the law knows no one as a poor man (Gill, 1993:24, 59). Mohlomi understood these maxims as essential for advancing administration and governance of public affairs, and they live on to this day.

From the above, there is no doubt that Mohlomi is a justified model of Basotho morality. He remains a very prominent moral figure in Basotho's history because of his unparalleled wisdom during his time. He was and is still regarded as one of the best examples of pre-colonial Lesotho's moral brilliance. He was a great man of his time. His greatness rested on his positive achievements as an impeccable model of ethics or morals in the society of his time: he was a celebrated doctor, an insatiable and optimistic traveller, a rainmaker, a political consultant, a philosopher, a chief, and a prophet (Machobane, 1978:5). He is celebrated for transforming the young short-tempered Moshoeshoe into a more humane individual and a 
famous and outstanding leader of his time. As he cultivated Mohlomi's teachings over many years, Moshoeshoe became a nation-builder, statesman, and diplomat of world renown (Gill, 1993:59-62).

Mohlomi is perhaps perceived as the last man to teach ethics in the administration and governance of public affairs in Basotho society - the values of peace, tolerance, love, and compassion. Mohlomi's radical, if not the unconventional manner of setting out to achieve a social order of justice, peace, and industriousness in an unstable and challenging world at the time, was incomprehensible to the society of his time. Nonetheless, it was a world in which Mohlomi sought to bring together internal morality and ethics and external social rules of order that arose from the social consciousness and consensus in the administration and governance of public affairs of the society of his time "to encourage awareness of societal conditions that tend to shape and constrain social change... [and] to engage in thought and action designed to create constructive social change" (Box, 2005: 1).

\section{Concluding remarks}

Basotho are described as people with a moral foundation (Coplan, 2003). That accolade stems from their association with Mohlomi, who taught them that it is to ethics they must look to give them Setho, philosophy of life whose agency is Botho. As a man of peace, a wise counsellor, and a "gnomic philosopher," Mohlomi's sayings live in the hearts of the Basotho and are preserved. Indeed, in modern-day Lesotho and South African province of Free State, Mohlomi is fondly regarded as an exemplar of what Binney et al dub ethically "living leadership born from the real joy and pain of leading [and] realities of leading" (Binney et al., 2005:vi). In discussing Mohlomi as a model of ethics and morality in public administration and governance, the article has provided insights into his philosophies' orientations, influences, and aspirations, which shaped his life, career, and scholarship. It has located his teachings, exemplar behavior, and works within Basotho history during pre-colonial southern Africa. It has discussed his contribution to endogenous knowledge production in southern Africa by locating his works within the enterprise of African social and political thought (philosophy) that he advocated and became its face. Beyond sentiments and hagiography, this article has provided a reason to believe that Mohlomi is indeed an impeccable model of ethics or morals in public administration and governance, with robust and insightful perspectives and an uncompromising position on major issues confronting society of his time. For his wisdom, courage, commitment and integrity, Mohlomi deserves our profound recognition for showing how to imagine a Setho-inspired administration and governance of public affairs in our contemporary times in which public administration and governance build on Botho principles is increasingly desirable and sought after commodity.

\section{References}

Amy, D. (1983). Teaching the Moral Analysis of Policy Issues. News for Teachers of Political Science, 36, 1-6. https://doi.org/10.1017/S0197901900002488

Arbousset, T. (1991). Missionary Excursion into the Blue Mountains Being an Account of King Moshoeshoe's Expedition from Thaba Bosiu to the Sources of the Malibamatso River in the Year 1840. Morija: Morija Archives. (Edited and translated by D Ambrose \& A Brutsch, 
1991).

Arbouset, T., \& Daumas, F. (1846). Narrative of an Exploratory Tour of the North-East of the Colony of the Cape of Good Hope. Cape Town: AS Robertson.

Ashton, E. H. (1967). The Basotho. Oxford: Oxford University Press.

Benney, G., Wilke, G., \& Williams, C. (2005). Living Leadership: A Practical Guide for Ordinary Heroes. London: Prentice Hall.

Box, R. C. (2015). Critical Social Theory in Public Administration. New York, NY: Routledge.

Casalis, E. (1861). The Basutos: Twenty Three Years in South Africa. London: James Nisbet. (Reprinted by Morija Printing Works for Morija Museum and Archives). https://doi.org/10.5479/sil.262374.39088000167106

Coplan, D. B. (2003, October 25-28). Imperial culture in countries without colonies: Africa and Switzerland. Paper presented to the conference, Nineteenth-century PEMS missionaries and the foundations of anthropology in Southern Africa. University of the Witwatersrand.

Couzens, T. (2003). Murder at Morija. Johannesburg: Random House.

Chedondo, M. (2019). Ethics and leadership: A critical analysis of cultural resources of ethical leadership in Southern Africa. Unpublished PhD thesis, University of KwaZulu-Natal. Retrieved November 10, 2020 from https://researchspace.ukzn.ac.za/handle/10413/16818

Doh, J. P., \& Stumpf, S. A. (2005). Handbook on Responsible Leadership and Governance in Global Business. Edward Elgar: Cheltenham. https://doi.org/10.4337/9781845425562

Dreyer, J. (2005, March 11). Interview with Jacobus (Cobus) Dreyer, Archaeologist, conducted by R P B Williams, regarding Moshoeshoe, on Friday, March 11, 2005, at 9:00 in Bloemfontein, University of the Free State.

du Preez, M. (2003). Pale Native Memories of a Renagade Reporter. Cape Town: Zebra Press.

du Preez, M. (2004). Of Warriors, Lovers and Prophets Unusual Stories from South Africa's Past. Cape Town: Zebra Press.

Eldredge, E. A. (2007). Power of Colonial Africa: Conflict and Discourse in Lesotho, $1870-$ 1960. Madison, Wisconsin: the University of Wisconsin Press.

Ellenberger, D. F. (1912). History of the Basuto: Ancient \& Modern (translated by J.C. MacGregor). London: Caxton, (Reprinted Morija, 1992).

Epprecht, M. (1992). Women, Class and Politics in Colonial Lesotho 1930-1964. Unpublished Ph.D. Dissertation, Dalhousie University. Retrieved August 20, 2019 from http://dalspace.library.dal.ca/handle/10222/55320

Futhwa, F. (2011). Setho - Afrikan Thought and Belief System. Alberton, South Africa: Nalane.

Gardner, J. W. (1990). On Leadership. New York: The Free Press.

Gill, S. J. (1993). A Short History of Lesotho. Morija, Lesotho: Morija Museum and Archives. 
Goggins, E. (2009). Responsible Leadership for all Centuries: How to become the Right Kind of Leader in every kind of situation. Retrieved September 20, 2019 from http://ethical-businessmanagement.suite101.com/article.cfm/responsible_leadership_for_all_ centuries

Guma, S. M. (1960). Morena Mohlomi Mor'a Monyane. Pietermaritzburg: Shuter and Shooter.

Johnson, D. T. (2019). The Importance of Ethics in Public Service. PA TIMES. Retrieved November 13, 2020 from https://patimes.org/the-importance-of-ethics-in-public-service/

Letseka, M. (2012). In Defence of Ubuntu. Studies in Philosophy and Education, 31(1), 47-60. https://doi.org/10.1007/s11217-011-9267-2

Lincoln, A. (1932). First Political Announcement. Retrieved October 12, 2020 from http://www.abrahamlincolnonline.org/lincoln/speeches/1832.htm

Maak, T., \& Pless, N. M. (Eds.) (2006). Responsible Leadership. New York: Routledge.

Machobane, L. B. B. J. (1978). Mohlomi: Doctor, Traveller, and Sage. Mohlomi, Journal of Southern African Historical Studies, 2, 5-27.

Machobane, L. B. B. J. (2008). Mohlomi's Philosophy of Peace and its Infusion in the southern African Region, 1720-1815, Morija, Lesotho: Friends of Morija Museum and Archives with Embassy of Ireland.

MacGregor, J. C. (1905). Basuto Traditions. Cape Town: Argus. https://doi.org/10.5479/sil.560231.39088009183211

Mahao, N. L. (2010). O se re ho morwa 'morwatowe!' African jurisprudence exhumed. XLIII CILSA, pp.317-336.

Mann, H. (1949). Twelfth Annual Report of the Board of Education Together with the Twelfth Annual Report of the Secretary of the Board of Education. Boston: Dutton and Wentworth.

Mapadimeng, M. (2009). Culture versus Religion: A Theoretical Analysis of the Role of Indigenous African Culture of Ubuntu in Social Change and Economic Development in the Post-apartheid South African Society. Politics and Religion, 3(1), 75-98.

Mbiti J. (1988). African Religions and Philosophy. Nairobi, Kenya: General Printers Limited.

Mofuoa, K. (2012). On Liberalism Individualism, Communitarianism and Ubuntu Society in South Afria. International Journal of Sudan Research, 2(2), 183-198.

Mofuoa, K. (2015). Chief Mohlomi: A Pioneer in Bridging Knowledge from Enterprises of Science, Business and Politics in Southern Africa in the 18th Century. The Journal of Corporate Citizenship, 60, 101-116. https://doi.org/10.9774/GLEAF.4700.2015.de.00009

Mofuoa, K. V. (2015). The Exemplary Ethical Leadership of King Moshoeshoe of Basotho of Lesotho in the Nineteenth Century Southern Africa. Journal of Public Administration and Governance, 5(3), 21-35. https://doi.org/10.5296/jpag.v5i3.8129

Mofuoa, K. (2016). Prospering in the southern Africa's VUCA world of the nineteenth century: A case of resilience of Basotho of Lesotho. Journal of Enterprising Communities: People and Places in the Global Economy, 10(2), 164-177. https://doi.org/10.1108/JEC-09-2014-0019 
Mofuoa, K. (2016). The Normative Grounding of Social Responsibility in African Emerging Markets: A Setho Ethics Approach. In M Al-Shammari and H Masri (eds.) Ethical and Social Perspectives on Global Business Interaction in Emerging Markets. Hershey PA, USA: Business Science Reference.

Mofuoa, K. (2018). The normative grounding of social responsibility in African emerging markets: A setho ethics approach". In Corporate Social Responsibility: Concepts, Methodologies, Tools, and Applications. Unites States of America: IGI Global.

Mofuoa, K. (2020). Stakeholder corporate social responsibility in the light of an African moral theory. PhD thesis, Charles Sturt University. Retrieved November 13, 2020 from https://researchoutput.csu.edu.au/en/publications/stakeholder-corporate-social-responsibility-i n-the-light-of-an-af

Mokhehle, N. (1976). Moshoeshoe 1 Profile Se-Moshoeshoe. Maseru, Lesotho: Mmoho Publications.

Mokolatsie, C. N. (2019). Revisiting virtue ethics and spirituality of botho: a study of indigenous ethics of character formation in the moral thought and practice of Basotho. Doctor of Theology thesis, University of South Africa. Retrieved November 13, 2020 from http://hdl.handle.net/10500/26809

Mothibe, T. (2002). State and Society, 1824-1833. In N Pule and M Thabane (Eds.) Essays on Aspects of the Political Economy of Lesotho 1500-2000, Morija: Morija Printing Works.

Phenix, P. H. (1961). Education: The Moral Curriculum. Time Magazine. Retrieved June 19, 2019 from http://www.time.com/time/magazine/article/0,9171,827220,00.html\#ixzz2atv6kJlt

Prozesky, M. (2016). Ethical leadership resources in southern Africa's Sesotho-speaking culture and in King Moshoeshoe I. Journal of Global Ethics, 12(1), 6-16. https://doi.org/10.1080/17449626.2016.1146789

Riep, D. M. M. (2011). House of the Crocodile: south Sotho art and history in southern Africa. PhD thesis, University of Iowa. https://doi.org/10.17077/etd.0dzbhfvg

Rosenberg, S., \& Veisfelder, R. F. (2013). Historical Dictionary of Lesotho. Leeds: Scarecrow Press.

Sanders, P. (1975). Moshoeshoe - Chief of the Sotho. London: Heinemann.

Sekese, A. (1978). Mekhoa Le Maele A Basotho. Morija, Lesotho: Morija Sesuto Book Depot.

Sloan, D. (1980). The Teaching of Ethics in the American Undergraduate Curriculum, 1876-1976. In D Callahan and S Bok (eds.) Ethics Teaching in Higher Education. The Hastings Center Series in Ethics. Boston, MA: Springer. https://doi.org/10.1007/978-1-4613-3138-4_1

van Wyk, G. (1996). The Heritage of Library of African Peoples: Basotho. New York: Rusen Publishing Group, Inc.

Waldman, D. A., \& Galvin, B. M. (2008). Alternative Perspectives on Responsible Leadership. Organizational Dynamics, 374(4), 341. https://doi.org/10.1016/j.orgdyn.2008.07.001 


\section{Copyright Disclaimer}

Copyright for this article is retained by the author(s), with first publication rights granted to the journal.

This is an open-access article distributed under the terms and conditions of the Creative Commons Attribution license (http://creativecommons.org/licenses/by/4.0/). 